University of Nebraska - Lincoln DigitalCommons@University of Nebraska - Lincoln

1983

\title{
Windward Fraction of the Total Mass or Heat Transport for Flow past a Circular Cylinder
}

S. Gökoğlu

NASA-Lewis Research Laboratories, Cleveland, $\mathrm{OH}$

D. E. Rosney

Yale University

Follow this and additional works at: http://digitalcommons.unl.edu/nasapub

Gökoğlu, S. and Rosney, D. E., "Windward Fraction of the Total Mass or Heat Transport for Flow past a Circular Cylinder" (1983). NASA Publications. 192.

http://digitalcommons.unl.edu/nasapub/192

This Article is brought to you for free and open access by the National Aeronautics and Space Administration at DigitalCommons@University of Nebraska - Lincoln. It has been accepted for inclusion in NASA Publications by an authorized administrator of DigitalCommons@University of Nebraska - Lincoln. 


\title{
Technical Note
}

\section{Windward Fraction of the Total Mass or Heat Transport for Flow past a Circular Cylinder}

\author{
S. Gökoğlu \\ NASA-Lewis Research Laboratories, Cleveland, $\mathrm{OH} 44135$ \\ and D. E. Rosner \\ Department of Chemical Engineering, Yale University, New Haven, CT 06520
}

The preferential deposition of material on the windward side of a bluff aerodynamic object is sometimes taken as evidence that the dominant mechanism of mass transport is the inertial impaction of large particles ${ }^{1}$ rather than the convective diffusion of vapors or small particles (e.g., Fuchs, 1964). However, although the latter mechanism is able to deliver material efficiently to the leeward portion of a bluff object (through the turbulence and recirculation), it is also true that below a particular Reynolds number $\left(\sim 10^{5}\right.$ for a cylinder in crossflow) even convective

\footnotetext{
${ }^{1}$ Even particles in the inertial range can find their way to the leeward surface through entrapment in the recirculation eddy or by "saltation" (Owen, 1964).
}

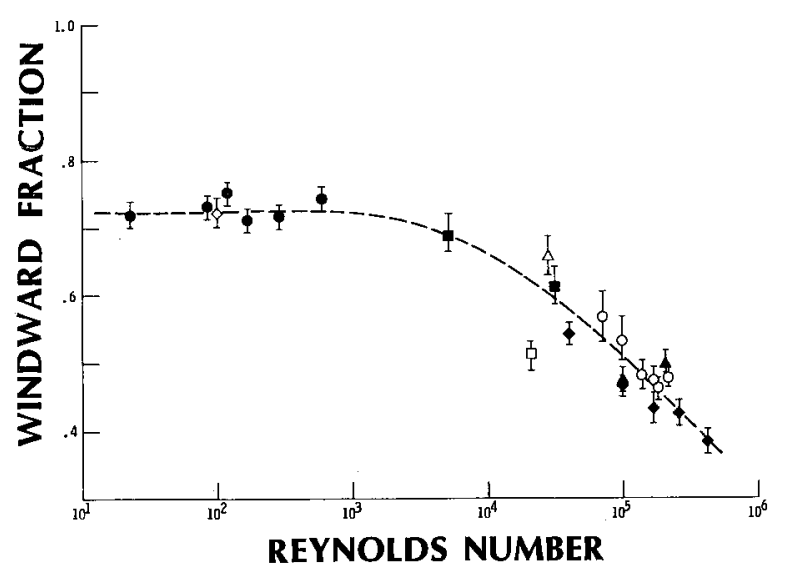

FIGURE 1. Reynolds number dependence of the windward fraction of the total mass or heat transfer for a circular cylinder in crossflow for a molecular diffusivity ratio of order unity. $O$, Giedt (1949); •, Eckert and Soehngen (1952); $\Delta$, Yardi and Sukhatme (1978); 4 , Giedt (1951); $\square$, Kruzhilin and Shvab (1935); a, Meel (1962); $\diamond$, Krall and Eckert (1970); Schmidt and Wenner (1941). 
mass collected for $-90^{\circ} \leq \theta \leq 90^{\circ}$ ) over the $\operatorname{Re}$ range $2 \times 10^{1}<\operatorname{Re}<4 \times 10^{5}$. The results (Figure 1), obtained from polar integrations of data from eight sources reveal that, first, for Reynolds numbers up to about $2 \times 10^{3}$ more than $70 \%$ of the total transfer occurs on the windward surface and, second, only at $\operatorname{Re}$ values above about $10^{5}$ does the windward percentage fall beneath $50 \%$. Thus, unless the windward fraction of the total transport to a circular cylinder in crossflow is significantly larger than, say, $72 \%$ or the Reynolds number is much larger than $10^{5}$, preferential windward surface mass transfer is not sufficient evidence of the dominance of inertial capture mechanisms over diffusional ones.

Helpful discussions with G. Santoro, concerning observations on the angular dependence of alkali sulfate salt deposits in burner rig experiments, are gratefully acknowledged. This work was supported in part by NASA grant NAG 3-201.

\section{REFERENCES}

Eckert, E. R., and Soehngen, E. (1952). Trans. ASME 74:346.

Fuchs, N. A. (1964). Mechanics of Aerosols. Pergamon, New York.

Giedt, W. H. (1949). Trans. ASME 71:378.

Giedt, W. H. (1951). J. Aeronaut. Sci. 18:725.

Krall, K. M., and Eckert, E. R. (1970). Heat Transfer 1970. FC7.5 Paris-Versailles, Vol. 3.

Kruzhilin, G. N., and Shvab, V. A. (1935). Zh. Tekhn. Fiz. 5:703.

Lowery, G. W., and Vachon, R. I. (1975). Int. J. Heat Mass Transfer 18:1229-1242.

Meel, D. S. (1962). Int. J. Heat Mass Transfer 5:715.

Owen, P. R. (1964). J. Fluid Mech. 20(2):225.

Schmidt, E., and Wenner, K. (1941). Heat transfer over the circumference of a heated cylinder in transverse flow, Forsch. Geb. Ing. Wes. 12:65-73.

Yardi, N. R., and Sukhatme, S. P. (1978). Proc. 6th Int. Heat Transfer Conf., Toronto, Canada.

Received 6 June 1983; accepted 13 June 1983 